\title{
Tikkun Olam. Judaistyczna wizja "naprawy świata” i jej ekologiczne eksplikacje
}

\author{
Barbara Nowicka \\ Wydział Filozofii Chrześcijańskiej \\ Uniwersytet Kardynała Stefana Wyszyńskiego \\ ul. Wóycickiego 1/3, 01-938 Warszawa, barbara.nowicka1987@gmail.com
}

\begin{abstract}
Streszczenie
Wżydowskiej teologii i filozofii problem natury wydaje się być ukryty, natura znajduje się niejako w cieniu człowieka. Jednak fakt degradacji środowiska naturalnego posiada niewątpliwie ogromny wpływ na ludzkość. Stąd zagadnienie ekologii i środowiska naturalnego są tematami coraz częściej pojawiającymi się również w myśli żydowskiej. Judaistyczna wizja ochrony środowiska bardzo często wiązana jest z konceptem Tikkun Olam co oznacza naprawę świata lub „odrestaurowanie” świata. Biblijne korzenie Tikkun Olam zachęcają nas do zbadania znaczenia środowiska naturalnego i człowieka w nim. Pojęcie Tikkun Olam zobowiązuje nas do nieustannej działalności wobec natury, którą powinniśmy poprawiać i otaczać ochroną. Przesłanie biblijne i jej transcendentne źródło mogą być znacznie silniejsze niż prawo ludzkie. Dlatego wizja judaistyczna ekologii może być również ciekawą propozycją w podejściu do opieki nad środowiskiem.
\end{abstract}

\section{Stowa kluczowe}

judaizm, ekologia

\section{Wstęp}

Przełom XIX i XX wieku stał się krokiem milowym w rozwoju przemysłowo - gospodarczym. Wraz z nim jednak nastała epoka postępującej degradacji środowiska przyrodniczego, która obecnie przybiera coraz większe tempo. Konieczność podejmowania działań na rzecz ochrony środowiska jest na tyle ważna, że podejmują ją różne dyscypliny naukowe (Dziekoński 2011: 179). W tym kontekście dużego znaczenia nabiera również religia z jej systemem etycznym jako nośnikiem wartości moralnych. W Polsce coraz prężniej rozwija się ekoteologia chrześcijańska, której zadaniem jest podkreślenie niebagatelnej roli prawdy objawionej oraz wypływającej z niej etyki dla troski o środowisko naturalne, czego na gruncie katolickim, kulminacyjnym wydarzeniem było wydanie przez papieża Franciszka encykliki Laudato Si!.

Problem degradacji środowiska i jego następstwa są i będą odczuwalne dla całej ludzkości, stąd religijny kontekst i możliwość wpływu etyki religijnej na działalność człowieka przybiera dużo szerszy kontekst niż tylko chrześcijański. Teologia i filozofia żydowska również poszukują normatywnych 
uzasadnień, które wskażą rolę i miejsce człowieka w świecie przyrody oraz wskażą zakres jego działań, które może i powinien podejmować wobec natury. Tę wizję jednostki bardzo szczegółowo odczytuje się z kart biblijnych i w niej również poszukuje się odpowiedzi na problemy współczesnego świata - także te związane $\mathrm{z}$ ochroną środowiska przyrodniczego. Bernard Szlaga badający zagadnienie ekologii podkreśla: „Biblia nie wylicza ile ton odpadów spada na kilometr kwadratowy, jak chronić lasy przed umieraniem, a powietrze przed kwaśnymi deszczami. Ale problem skażenia środowiska, czyli mieszkania człowieka, Biblia zna” (Szlaga 1998: 57). Skażenie jest tutaj rozumiane bardzo symbolicznie, jako swoiste zatrucie decyzją człowieka. „Decyzją, która była grzechem, bo stanowiła wypowiedzenie posłuszeństwa Bogu. Natura jest tylko naturą, ale udziela jej się rozumność człowieka, który ją porządkuje, nią zawiaduje, czyni ją sobie poddaną, dokładnie tak jak chciał tego Stwórca" (Szlaga 1998: 55). Ujawnia się zatem czysto antropogeniczne pochodzenie wszelkich zgubnych dla człowieka nieprawidłowości w funkcjonowaniu świata, również świata przyrodniczego.

Jak zatem problem ekologii i działania na rzecz środowiska naturalnego rozstrzyga judaizm? Zawarty w tytule hebrajski termin Tikkun Olam oznacza „naprawa świata”, „odbudowa świata”, czy też „doskonalenie świata”. Wezwanie do swoistego odrestaurowania świata pojawiło się już w początkach formowania się religijności żydowskiej. Dziś termin ten jest wielowymiarowy, znajdujący swój wyraz również w amerykańskiej popkulturze, ale staje się także manifestem mającym skłonić nas do podejmowania działań na rzecz ochrony środowiska.

Warto dodać, że cytowane fragmenty biblijne pochodzą z polskiego przekładu Tory, te bowiem dużo lepiej oddają charakter myśli żydowskiej. Wówczas zostały oznaczone hebrajską nazwą księgi - Bereszit. Tam jednak, gdzie dosłowne tłumaczenie nie jest konieczne dla wyciągnięcia esencji tekstu fragmenty zostały oznaczone polskim nazewnictwem ksiąg biblijnych. Polskie nazewnictwo jest bowiem dużo bardziej rozpowszechnione, co ułatwia zarazem weryfikację niniejszego tekstu ze źródłem.

\section{Tikkun Olam}

Tak jak wiele słów, czy zwrotów pochodzących z języka hebrajskiego powyższy termin jest używany w formie nieprzetłumaczalnej, co oznacza, że w każdym języku stosuje się jego oryginalne brzmienie. Chociaż jest zwrotem wypływającym z judaizmu, współcześnie stało się hasłem pojawiającym się w świecie popkultury i polityki, jak podczas kampanii prezydenckiej w Stanach Zjednoczonych w 2012 roku (Web-o1). Samo wezwanie do naprawy świata brzmi niezwykle doniośle. W kontekście judaizmu realizacja powyższego przesłania przybiera wiele form i staje się konceptem, który nieustannie podlega interpretacjom. Zgodnie z żydowską tradycją przesłanie naprawy świata wypływa $\mathrm{z}$ ksiąg religijnych i pierwotne znaczenie odnosiło się do życia duchowego. Byron Sherwin wskazuje, że współcześnie termin ten jest szczególnie popularny wśród wyznawców liberalnego nurtu judaizmu, a jego eksplikacja przybiera bardzo zróżnicowane formy. Oznacza wszelką działalność społeczną, podkreślając w ten sposób postęp socjalny, ekonomiczny i polityczny (Webo1). Pojawia się także w kontekście wprowadzania nowych reform w prawie, ale również jako wypełnienie religijnych obowiązków, takich jak składanie datków dla ubogich, czy działalność w formie wolontariatu (Web-O2). Tikkun Olam stało się zatem synonimem każdej aktywności człowieka, której celem jest pozytywna zmiana, ze szczególnym uwzględnieniem działania wspólnotowego, wykraczającego poza indywidualne potrzeby.

\subsection{Przyrodnicze przywrócenie}

Lawrence Troster podaje jednak kolejne znaczenie konceptu Tikkun Olam, które pojawia się jako działalności na rzecz środowiska naturalnego (Web-o3). Współcześnie to rozumienie nabiera szczególnego wymiaru. Zgodnie z teologią judaistyczną człowiek 
choć stanowi integralny element całego ekosystemu, zajmuje w nim miejsce wyjątkowe. Spośród całego stworzenia, tylko człowiek posiada realną możność oddziaływania na środowisko naturalne, w którym żyje i w dużej mierze to od niego zależy w jakim stanie się ono zachowa. Wobec postępujących zmian klimatycznych, degradacji przyrody i wielu innych problemów środowiskowych występujących już na skalę globalną, wezwanie do naprawy świata, staje się nie tylko hasłem, ale koniecznością czynnego działania. W tym miejscu należy wyjaśnić, że mówiąc o postawie ekologicznej koncentrujemy się na bardzo szerokim rozumieniu tego pojęcia. Następuje bowiem pewna nieścisłość między językiem codziennym, a dyskursem akademickim. Wszelką działalność mającą na celu ochronę środowiska zazwyczaj ujmuje się pojęciem ekologii, co w rzeczywistości naukowej funkcjonuje w zakresie sozologii. Ekologia w rozumieniu nauki badającej relacje między organizmami a środowiskiem, a także wszelkie pochodne od niej nauki, w przypadku niniejszego artykułu, z sozologią na czele, jest pojęciem współczesnym, które ukształtowało się dopiero w XX wieku (Banaszak, Wiśniewski 1999: 23-24). Jednak we wszystkich znalezionych opracowaniach z zakresu dbałości o środowisko w ujęciu judaizmu występuje pojęcie ekologii, dlatego też przy tym terminie pozostanę.

Zanim jednak przejdziemy do analizowania ekologicznego kontekstu „naprawy świata", należy przyjrzeć się historyczno teologicznemu tłu, na którym budowano przyrodniczy kontekst Tikkun Olam. Dla narodu żydowskiego biblijna tradycja jest bowiem spoiwem, które integruje nawet niereligijne środowiska. Stąd zwrócenie się do źródeł ma tak zasadnicze znaczenie. Zatrzymanie się nad historycznym tłem pozwoli nie tylko usystematyzować wiedzę, ale ukaże, że w etyce judaistycznej każda norma moralna ma głębokie uzasadnienie w prawie wypływającym z transcendentnego źródła, które akceptuje zarazem subiektywne ludzkie kryteria do uzasadniania nauczania wypływającego z tradycji (Szczerbiński 2001:
41). Stąd mówiąc o problematyce współczesnej, jesteśmy zobowiązani do zaczerpnięcia ze źródeł tradycji judaistycznej.

\subsection{Biblijne źródła Tikkun Olam}

Jill Jacobs zauważa, że podobnie jak słowa Shalom, czy Szabat, również Tikkun Olam nie pojawia się w Biblii, a jednak jest znane jako jedno z bardziej popularnych zwrotów hebrajskich, a dla wielu nawet stanowi filar judaizmu (Web-o4). Levi Cooper źródeł słowa Tikkun poszukuje w biblijnej Księdze Koheleta (1.15), gdzie hebrajskie „t-k-n” pojawia się w sensie porządkowania, naprawiania, kształtowania. W późniejszej tradycji Tikkun zostawało przekształcane i używane w wielu kontekstach. Między innymi w ten sposób określano przygotowywanie znaczących wydarzeń, komponowanie liturgii, poprawianie tekstów liturgicznych, czy dokonywanie przeliczeń niezbędnych przy tworzeniu kalendarza żydowskiego (Web-o4). Rzeczownik Olam, podobnie jak czasownik Tikkun, również zawiera wiele znaczeń. W prostym tłumaczeniu to „świat”, a w tym przypadku oznacza tyle co świat w kontekście geograficznym, ale również społeczeństwo, wspólnota, wszechświat, sfera duchowa, czy wieczność (Web-o4). Byron Sherwin, powołując się na badania Sagit Mor podkreśla, że wyrażenie Tikkun Olam znajduje się już w najwcześniejszych pismach hebrajskich, między innymi w Misznie, która jest jednym z podstawowych tekstów rabinicznych, zawierającym normy postępowania prawnego. W pierwotnym znaczeniu pojęcie Olam - świat odnosiło się wyłącznie do żydowskiej kultury i cywilizacji, nie do świata w znaczeniu geograficznym, czy środowiska naturalnego. Było określeniem skupiającym się na różnorodnych celach, od interpretacji prawa określając zasady ekonomicznych transakcji, poprzez przepisy liturgiczne, aż po zabezpieczenie kobiet żydowskich, które po rozwodzie zostawały bez opieki. Miało podkreślać zatem znaczenie żydowskiego prawa, kultury dla zachowania dziedzictwa hebrajczyków (Web-01). 
Jako cały zwrot Tikkun Olam występuje w modlitwie Aleinu, którą każdy pobożny żyd odmawia trzy razy dziennie. Tradycja głosi, że głównym zadaniem judaizmu jest misja polegająca na „doskonaleniu świata na skutek przybliżania ludzkości Boga" (Jędrzejewski 2012: 187). Zgodnie ze słowami wspomnianej modlitwy: Letken olam bemalchut Szadaj, celem istnienia i działalności Żydów jest „doskonalenie świata za pośrednictwem Królestwa Wszechmogącego (Jędrzejewski 2012: 187). Przybliżanie Królestwa Bożego to życie zgodne $\mathrm{z}$ nakazami prawa zachowanego w Torze, czyli przekładanie w czyn prawa Bożego. Pojęcie jednak o tyle bogate, co złożone, z którego wyjaśnieniem często borykają się sami wyznawcy judaizmu. Pierwotne znaczenie terminu Tikkun Olam odnosiło się zatem do życia religijnego i społecznego, które związane było z jak najlepszym funkcjonowaniem jednostki i ogółu w świecie żydowskim. Wydaje się, że celem Tikkun Olam było wspieranie wyznawców judaizmu dla zachowania jak najlepszej kondycji religijności żydowskiej, a przy tym również społeczeństwa żydowskiego. Współcześnie jednak ten paradygmat uległ zmianie. Wpisując w wyszukiwarkę internetową powyższy termin, napotykamy szereg znaczeń, które oscylują od aktów religijnych przez działalności wolontariacką na rzecz ubogich, aż po nauki przyrodnicze, politykę czy ekonomię. Taka niejednoznaczność przekazu Tikkun Olam, wynika z niejednorodności samego judaizmu. Inaczej tę ideę odczytują żydzi ortodoksyjni, a inaczej żydzi z liberalnego nurtu.

Analizując wskazówki jakie podają żydowscy rabini, odnajdujemy dwa nurty, w których jesteśmy pouczani jaką postawę przyjąć wobec zalecenia naprawy świata. Pierwszy nurt odnosi się do świata duchowego człowieka. Ten sposób rozumienia wynika z wizji, że świat zewnętrzny, który został stworzony przez Boga jest doskonały i człowiek nie tylko nie musi, ale nawet nie może go poprawić. Ortodoksyjny rabin Bostonu Yitzhak Aharon Korff podkreśla, że człowiek nie jest też poinstruowany w jaki sposób tej naprawy miałby dokonywać, ani nawet nie jest zobligowany do podejmowa jakichkolwiek działań. W przykazaniach Tory zostaliśmy jednak pouczeni w jaki sposób postępować. Wszelka niedoskonałość świata, a w nim człowieka, jest spowodowana nieuporządkowaniem wewnętrznego życia. Właściwe rozumienie pojęcia Tikkun Olam - stwierdza Korff kieruje nas na zmianę siebie, zmianę postępowania i wypełnianie micwot - przykazań (Web-05).

Amerykańscy zwolennicy liberalnego judaizmu przychylają się jednak do nieco odmiennego stanowiska. Podkreślają religijne źródła Tikkun Olam, tak jak ma to miejsce w judaizmie ortodoksyjnym, ale dostrzegają możliwość wykorzystania znaczenia „naprawy świata” w dużo szerszym kontekście niż tylko duchowy czy liturgiczny. Odnosząc się oczywiście do tradycji i religijnych źródeł stwierdzają, że działalność na rzecz społeczeństwa jest tak samo ważna jak wkładanie religijnego stroju podczas modlitw synagogalnych (Web-o6). Stąd współcześnie w kręgach liberalnych Tikkun Olam to tyle co działalność polityczna, dążenie do sprawiedliwości społecznej, czy oddolna aktywność społeczna (Web-04, Web-05). Lawrence Troster dodaje, że współczesna teologia żydowska koncentrująca się na sprawiedliwości społecznej, zwraca uwagę, że w procesie naprawiania świata, większą rolę ma ludzka wola niż boskie działanie (Web-o3).

Teologia judaistyczna dostrzega zatem konieczność nieustannego działania, na rzecz poprawy samego siebie, ale również świata zewnętrznego. Odkąd ingerencja człowieka w środowisko naturalne przyjęła tak wysoki poziom, że jego prawidłowe funkcjonowanie zostało zagrożone, a tym samym zagrożenie pojawiło się również wobec człowieka, uznano, że konotacje, jakie posiada pojęcie Tikkun Olam oraz jego popularność w świecie żydowskim, może przypominać również o konieczności działalności proekologicznej mającej na celu dążenie do doskonałości świata przyrodniczego. Jaki zatem świat jest światem doskonałym? 


\section{3. Świat doskonały}

Dostrzeżenie potrzeby podjęcia różnorodnych form działalności na rzecz naprawy świata musi wynikać z faktu, że ten świat, w którym żyjemy aktualnie nie jest doskonały. Jednak judaizm nie definiuje wprost czym jest ta doskonałość. Mimo to racjonalny człowiek zdaje sobie sprawę, że istnieje wiele wymiarów ludzkiej egzystencji i świata zewnętrznego, które budzą niepokój, a zarazem mobilizują do podejmowania działań w celu dążenia do polepszania kondycji swojej i świata otaczającego. Stąd spektrum koncepcji wypełniania Tikkun Olam jest tak bardzo szerokie (Web-02). Skoro w całej rozpiętości możliwości wypełniania Tikkun Olam znajduje się również perspektywa ekologiczna oznacza to, że są przynajmniej dwa powody, dla których ochrona środowiska jest tak ważna. Po pierwsze istnieją obiektywne przesłanki, dla których ekologia, a w niej dbałość o środowisko naturalne, jest zasadna. Po drugie, jeżeli poruszamy się w zakresie judaizmu, to wskazanie czym jest postawa proekologiczna winna mieć umocowanie w prawie religijnym. O tym, że ochrona środowiska jest dziś zadaniem koniecznym nie trzeba nikogo przekonywać. Warto jednak w tym momencie zatrzymać się na drugim aspekcie z wymienionych powyżej. Mówiąc o ekologii w perspektywie judaizmu, a w szczególności o jej źródłach, będziemy poruszali się na krawędzi nauk przyrodniczych i teologii. Skoro w dyskursie judaistycznym pojawiło się polecenie naprawiania świata w kontekście środowiska naturalnego, to musi to oznaczać, że dla wyznawców tej religii istnieje punkt odniesienia wskazujący co oznacza doskonałość świata. Innymi słowy, jak zaznacza Troster, dla wyznawców judaizmu konieczna jest swoista środowiskowa eschatologia, która będzie zgodna z tym jak funkcjonuje świat (Webo3). Dlatego w tym momencie należy zatrzymać się na biblijnej wizji doskonałego świata.

\subsection{Doskonałość stworzenia}

Biblia przekonuje o doskonałym świecie i utracie tej doskonałości już w opisie stworzenia. Zgodnie z Księgą Rodzaju - Bereszit świat pierwotny, powstały w wyniku woli Boga był „bardzo dobry”, tak bowiem podsumowany zostaje każdy akt stwórczy. Doskonałość wynika zatem już z doskonałości samego Stwórcy. Absolutny Bóg nie może stworzyć dzieła niedoskonałego. Doskonałość zawierała się między innymi w harmonii świata ożywionego i nieożywionego, w uporządkowaniu wszystkich sfer, całego kosmosu, i umiejscowieniu w nim człowieka. W jednym z przypisów do księgi Bereszit czytamy, że Bóg zachował się jak gospodarz, który zanim zaprosił gościa - człowieka, przygotował najpierw stół nakrywając go i zastawiając (Tora Pardes Lauder 2001: 12). Świat był dobry, zatem stworzony najlepiej, doskonale dla człowieka. W opisie stworzenia czytamy, że dopiero gdy wszystko było gotowe, przestrzeń, w której miał żyć, Bóg stworzył człowieka wyposażając go w szczególny dar - rozum i wolność. Otrzymał wówczas również jeden, ale za to bardzo charakterystyczny zakaz „I przykazał Bóg człowiekowi: Ze wszystkich drzew w ogrodzie możesz jeść, ale z Drzewa Poznania dobra i zła, z niego nie jedz, bo w dniu, gdy zjesz niego, na pewno umrzesz" (Bereszit 2,17). Kosztując owoc człowiek wystąpił przeciwko woli Stwórcy, dopuścił się zburzenia doskonałego porządku, co będzie miało zasadniczy wpływ na całe dzieje ludzkości. Również ziemia, która miała dawać plon i pożywienie została wówczas skażona: „A do człowieka powiedział: Ponieważ posłuchałeś głosu swojej żony i zjadłeś z drzewa, o którym ci przykazałem, mówiąc 'Nie jedz z niego' - przeklęta jest ziemia z twojego powodu, w cierpieniu będziesz $\mathrm{z}$ niej jadł po wszystkie dni twojego życia" (Bereszit 3,17).

Biblijna historia ukazuje zatem doskonałe dzieło stworzenia i moment utraty tej doskonałości. Odtąd człowiek wciąż musi podejmować trud naprawiania. Powyższa teologiczna wizja pokazuje zatem ponadczasowość koncepcji Tikkun Olam, czyli wezwania do naprawy świata, która wynika z natury człowieka skłonnego do niszczenia tego co dobre. Zrozumienie 
antropologicznej wizji, będzie miało również zasadniczy wpływ na doskonalenie świata, również w aspekcie środowiska naturalnego.

\subsection{Biblijne podstawy ekologii}

Podejmując temat ekologii w judaizmie należy zdać sobie sprawę, że dotyczy ono zjawiska, które w tradycji żydowskiej trwało od zawsze, jednak przez wieki nie było w ten sposób nazywane. Księga Rodzaju/ Bereszit stanowi źródło zasad obowiązujących w relacjach człowiek - Bóg, ale również człowiek - pozostałe stworzenia natury; niezależnie czy mówimy o świecie fauny czy flory. Arthur O. Waskow stwierdza, że prawdopodobnie najgłębiej relację między człowiekiem a naturą określają dwa słowa wywodzące się z języka hebrajskiego: Adam i Adamah. „Pierwsze oznacza «ludzkie bycie»; drugie «ziemia». Te dwa słowa są połączone, żeby nauczyć nas o tym, że ludzkie bycie i ziemia splatają się ze sobą (Waskow 200o: vii). Skoro zatem Bóg tworzy człowieka na swój własny obraz, przekazuje mu świat, który stworzył, to tym samym zakotwicza w nim etykę odpowiedzialności za dzieło stworzenia. To, że natura została stworzona, nie oznacza, że jest doskonała i nie wymagająca ingerencji. Wprost przeciwnie, wymaga oddziaływania na nią, jednak tym oddziaływaniem nie ma być bezmyślna eksploatacja, ale dbałości. Stąd Bóg przekazuje człowiekowi przykazania, które mają mu w tym pomóc (Tirosh-Samuelson 2006: 26).

W księgach biblijnych zostało zawartych wiele przykazań dotyczących relacji człowieka z naturą przyrodniczą. Do najpowszechniejszych przykazań, które dotyczą traktowania zwierząt wymienia się: „zakaz wykorzystywania pracy jakichkolwiek zwierząt w Szabat (Pwt 5), zakaz uniemożliwiania pracującemu na polu zwierzęciu spożywania takiej ilości pokarmu, na jaką ma ochotę (Pwt, 25), zakaz sprzęgania razem zwierzęcia małego i dużego, ponieważ ze względu na różniącą je siłę i wielkość oba by się męczyły, nakaz pomocy męczącemu się zwierzęciu pracującemu dla człowieka, niezależnie jaki mamy stosunek do jego właściciela. Wśród przykazań boskich wyróżniamy te, które winny obowiązywać żydów, ale również takie, które dotyczą całej ludzkości. Od imienia Noego pochodzą przykazania, których powinien przestrzegać każdy człowiek, niezależnie od wyznawanej wiary. I tak wśród przykazań Noachidów widnieje zakaz obcinania członków żywym zwierzętom. Ten przepis zostaje jednak dużo bardziej rozszerzony i obejmuje zakaz polowań, których celem ma być forma rozrywki. Tradycja biblijna wspomina tylko dwóch myśliwych Nimroda, potomka Noego, który jednak według tradycji nie był Hebrajczykiem, oraz Ezawa. Obaj w kulturze żydowskiej są uznawani jako postaci negatywne, pozbawione żydowskiego ducha. Ponadto zakazane są wszelkie zabawy, w których zwierzę w jakikolwiek sposób mogłoby zostać okaleczone. Również tak kontrowersyjny w ostatnim czasie ubój rytualny, posiada szeroki spis norm w jaki sposób powinien nastąpić, aby zwierzę jak najmniej cierpiało (Jędrzejewski 2012: 344, Gordis 1995: 329). W tym kontekście szczególnego znaczenia nabierają także przepisy koszerności określające rytualną czystość rzeczy, przede wszystkim zaś żywności. Ich źródłem są przykazania zawarte w Księdze Powtórzonego Prawa i Księdze Kapłańskiej. Zawierają one nie tylko antropocentryczną, ale również ekocentryczną wartość. Jak zauważa David Vogel, duża liczba zwierząt wymienionych jako niekoszerne, a więc nieprzeznaczonych do spożywania, znajduje się na liście zwierząt szczególnie chronionych przez współczesnych działaczy na rzecz ochrony gatunków zagrożonych wyginięciem. Do tych gatunków zalicza się przede wszystkim te, które podczas rozmnażania nie wydają licznego potomstwa, a więc ich ciągłość przetrwania jest narażona na niebezpieczeństwo (Web-07).

Ta harmonia dotyczy również flory. Tutaj jednym z najważniejszych przykazań staje się przestrzeganie roku szabatowego, kiedy ziemia odpoczywa, nie uprawia się 
jej, a plony, które wyda pozostawiane są dla ubogich. Innym przykazaniem jest zakaz, szczególnie w czasie wojen, niszczenia kwitnących drzew owocowych, gdyż ich owoc wkrótce może stać się jedynym źródłem pożywienia. Stąd wypływa również kolejne wskazanie pochodzące z Miszny Kiduszin - zakaz niszczenia wszystkiego, co przynależy do użyteczności publicznej, między innymi naturalnych źródeł wody (Gordis 1995: 332).

To tylko najbardziej znamienne przykłady obrazujące wartość środowiska naturalnego w judaizmie, które zawierają się w dwóch podstawowych zasadach. Po pierwsze to właściwe traktowanie zwierząt; po drugie właściwa postawa wobec przyrody nieożywionej (Gordis 1995: 328). Powyższe argumenty wzbudzają najwyższe uznanie. Powstaje jednak pytanie, czy są możliwe do spełnienia współcześnie. O ile powrót do natury, przywracanie jej pierwotnego obrazu i formy staje się coraz bardziej popularne, o tyle wydaje się, że ortodoksyjne przestrzeganie powyższych nakazów dziś wymagałoby dokonania znacznych zmian w funkcjonowaniu ludzkości. Nie jesteśmy bowiem w stanie zatrzymać postępującego rozwoju technologicznego, który w znaczny sposób kłóci się z wymienionymi wyżej wskazaniami. Zakaz niszczenia kwitnących drzewek w czasie wojny nie ma dziś szczególnego zastosowania. Z kolei przepisy dotyczące pracy zwierząt w polu, również nijak mają się do rzeczywistości. W tej sytuacji judaizm reformowany próbuje przekształcić biblijne prawo na potrzeby współczesności. Wartość środowiska naturalnego motywuje się już nie tyle przykazaniami biblijnymi, ile wskazaniem, że nasze życie tu i teraz jest ściśle uzależnione od tego w jaki sposób będziemy z nią postępować. Człowiek znając swą pozycję wobec świata naturalnego, staje na straży o jej dalsze losy.

\subsection{Naród Świętej Ziemi}

Judaizm nie udziela odpowiedzi na pytanie jak długo i co należy udoskonalać aby świat przyrody był w stanie doskonałym.
Ellen Bernstein stwierdza, że tematyka ekologiczna zdaje się być niejako ukryta w tej religii monoteistycznej. Odnajduje trzy powody dlaczego następuje taki stan rzeczy. Po pierwsze współcześni żydowscy badacze koncentrują się przede wszystkim na historii judaizmu, a zatem tematyka natury umykała ich zainteresowaniu. Po drugie odczytanie świętych ksiąg judaizmu nie jest zadaniem łatwym, stąd pojawia się trudność w dotarciu do głębi ich przekazu i odkrycia wielu wymiarów tekstów. Trzecim powodem „ukrycia” ekologii jest błąd formalny, polegający na niewłaściwym zadawaniu pytań. Pytania typu: „Co mówi judaizm na temat kryzysu ekologicznego?”, bądź pytanie o środowisko, czy naturę są w tym wypadku sformułowane niewłaściwe, gdyż dotyczą współczesnej problematyki, nieznanej starożytnym Izraelitom. Natura była integralnym elementem ich życia wyznaczającym pewien cykl. Terminy „natura” czy „środowisko" nie miały znaczenia (Bernstein 1998: 13). Dlatego w ujęciu judaizmu postawa proekologiczna, ochrona przyrody nie będzie rozważana w kategoriach utylitarystycznych, czyli opłacalności takiego stylu życia dla człowieka i dla przyrody zarazem. Tutaj działania, które określiliśmy również mianem Tikkun Olam będą rozważane w kontekście świętości. Należy zatem troszczyć się o to co zostało uświęcone przez samego Stwórcę.

Początki narodu izraelskiego są ściśle związane z ziemią, przyrodą, naturą, która była ich domem i karmicielką. Ogród Eden, Morze Czerwone, góra Synaj, rzeka Jordan czy wody Babilonu to miejsca, których konotacje kierują myśl w stronę Izraelitów. Najważniejsze wydarzenia dla narodu żydowskiego, ale również dla wyznawców trzech największych religii monoteistycznych działy się w wyżej wymienionych miejscach. Zamieszkując półpustynną ziemię, której plony zależne były od opadów deszczu, czy rosy, stworzyli społeczeństwo oparte na rolnictwie, w którym czynnik przyrodniczy decydował o ich przetrwaniu. Przyroda kształtowała również cykl życia 
starożytnych Izraelitów, który związany był z pracami polowymi, a podsumowaniem tej działalności były święta upamiętniające ważne wydarzenia oraz oddające cześć naturze za plony, które zebrali. Święto Sukkot zwane świętem namiotów; Pessach rozpoczynające się pierwszą pełnią wiosenną i początkiem zbiorów jęczmienia i Shavuot, które było świętem zbiorów. (Tirosch-Samuelson 2010: 26). Te pierwotnie rolnicze święta nabrały historyczno - religijnego znaczenia w Biblii, łącząc je z ucieczką Izraelitów z Egiptu, wyzwolenia z niewoli egipskiej oraz nadanie Mojżeszowi Tory.

Rolnicze święta zostały przyswojone przez judaizm rabiniczny. Sakralizacja natury i stworzenia została wyrażona w przykazaniach i codziennych modlitwach poprzez oddawanie czci Stwórcy: „Ty, który w swej dobroci stworzyłeś każdy dzień”. Rytm codziennych modlitw został podporządkowany rytmowi dnia, który się zmienia w ciągu roku. O związaniu narodu żydowskiego z ziemią, której należy się cześć, w sposób szczególny ma przypominać wspomniane wcześniej święto Sukkot. Pierwotnie miało być wydarzeniem podsumowującym zbiory i przygotowaniem do zimowej pory deszczowej. Zostało związane z wyzwoleniem Izraela z niewoli egipskiej. W przykazaniach Izraelici zostali zobligowani do przebywania w namiotach przez siedem dni, kiedy to mają rozpamiętywać czas, który spędzili na pustyni uciekając z Egiptu, kiedy to byli całkowicie zdani na warunki naturalne, bezpośrednio podlegające władzy Boga (Tirosch-Samuelson 2010: 28). I dziś w święto namiotów żydzi budują namioty w pobliżu swoich domów lub na balkonach mieszkań. Tradycja wypływająca z kultury agrarnej zostaje podtrzymywana w postaci świąt, które dziś odgrywają zasadniczą rolę nawet wśród niereligijnych żydów. Nawiązanie do źródeł, z których wywodzą się Izraelici ujawnia się w postaci celebracji podkreślających ich pochodzenie, a zarazem wartość płodów ziemi dla przetrwania narodu żydowskiego w najtrudniejszych momentach.

\section{Inkorporacja konceptu Tikkun Olam}

Odnosząc się do praktyki i zastosowania konceptu Tikkun Olam w kontekście ekologicznym Lawrence Troster zauważa, że konieczne jest połączenie dwóch dziedzin - teologicznej i współczesnych nauk przyrodniczych, które pokazują jak ten świat funkcjonuje, również w podłożu środowiska naturalnego (Web-o3). Teologia wiedzie nas do dostrzeżenia wartości przyrody, które wybitny żydowski teolog i filozof Abraham Joshua Heschel nazywa pięknem, siłą i majestatem (Heschel 2008: 48). Wydaje się, że usnuta na tradycji osnowa wokół natury te wartości doskonale uwydatnia. Jednak perspektywę teologiczną należy rozszerzyć o filozoficzną. Nauki przyrodnicze wskazują praktyczny wymiar dbałości o środowisko, udzielają rad w jaki sposób jednostkowo możemy przyczynić się do ochrony przyrody, co w efekcie będzie miało charakter globalny. Z drugiej strony filozofia przyrody jako nauka humanistyczna daje teoretyczne podwaliny wskazując wartość aksjologiczną czy etyczną środowiska naturalnego, co uzupełnia nauki przyrodnicze. Jest to o tyle ważne, że ochrona przyrody i działalność proekologiczna przestaje być wytworem czyjejś fantazji, a posiada niepodważalne argumenty za jej zasadnością. Włodzimierz Tyburski podkreślając znaczenie filozofii ekologicznej, a więc jednego z komponentów filozofii przyrody wyznacza dwa ujęcia: „filozofia ekologiczna, w ujęciu retrospektywnym, zdąża do ukazania tego zespołu uwarunkowań filozoficznych, kulturowych i światopoglądowych, które w dobie nowożytnej - a więc w ostatnich kilku stuleciach - generowały myślenie skrajnie utylitarne, pozytywistyczno - technokratyczne, a którego praktyczne konsekwencje okazywały się tak bardzo niebezpieczne dla świata przyrody. W ujęciu prospektywnym filozofia ekologiczna wnosi swój znaczący wkład w dzieło budowania nowego myślenia o człowieku i świecie przyrody, włączając się aktywnie w działania mające na celu projektowanie wizji przyszłości 
i budowanie modelu cywilizacji zorientowanej na potrzeby ekologiczne" (Tyburski 2006: 7-8).

Wracając jednak do postulatu Trostera, aby łączyć nauki przyrodnicze i teologię, pojawia się jeszcze jeden aspekt wiążący teologię i filozofię, mianowicie związany z etyką, która ma umocowanie teologiczne. Ta mając źródła, które wychodzą poza rozumowanie czysto ludzkie, a posiadające źródło transcendentne, staje się dużo bardziej sugestywna. Religia, wbrew pozorom ma tutaj nieocenione znaczenie. Jak zauważa Roger S. Gottlieb: „powinniśmy pamiętać, że dla setek milionów ludzi religia pozostaje arbitrem i repozytorem najgłębszych moralnych wartości. W tym kontekście religia zapewnia bogaty zasób do mobilizowania ludzi do podejmowania akcji politycznych" (Gottlieb 2006: 12).

Powyższy aspekt teoretyczny pozwala na rozwiązanie problemu, w który często wpadają zarówno działacze pro-ekologiczni, jak i oponenci tychże ekologów. Pojawia się bowiem rozdwojenie pomiędzy postawą antropocentryczną i ekocentryczną, a przez to związaną z nimi dominacją człowieka w przyrodzie bądź też przyrody nad człowiekiem. Wypływająca z Biblii nauka dotycząca relacji pomiędzy człowiekiem a środowiskiem naturalnym oraz rolą człowieka w kształtowaniu natury daje ogromny asumpt przemyśleń nad postawą jednostki wobec przyrody. Naprawa świata w tym aspekcie jest wciąż konieczna. Jednak zagadnienie etyki środowiskowej w kontekście judaizmu jest zagadnieniem stosunkowo nowym, dlatego wielu żydowskich uczonych poszukuje dziś normatywnych rozwiązań etycznych w kwestiach związanych z szeroko pojmowaną ekologią. Wielu odczytuje święte teksty statycznie, literalnie. Zgodnie z Księgą Rodzaju dzieło odnawiania świata jest trwającym procesem, którego Bóg dokonuje każdego dnia, a człowiek zajmuje wyjątkowe miejsce w tym dynamicznym obrazie boskiego świata. Razem jesteśmy częścią natury, ale niejako poza nią (Web-o8).
Przenosząc znaczenie naprawy świata z aspektu teoretycznego na ściśle praktyczny należy zwrócić uwagę na relację człowiek - natura. Żydowscy myśliciele wskazują bowiem, że o ile biblijny przekaz stawia człowieka w roli opiekuna nad stworzeniem, o tyle współcześnie ten paradygmat zostaje odwrócony. Coraz częściej to naturze przypisuje się nadrzędną rolę wobec człowieka. Chcąc mówić o powiązaniach człowieka ze środowiskiem w judaistycznym ujęciu należy zaznaczyć, że pomimo szczególnego powiązania, o którym wspomina Waskow, judaizm wprowadza zasadniczą różnicę między pozycją człowieka a pozostałym stworzeniem.

\subsection{Człowiek dla przyrody}

Mojżesz Majmonides, autor najważniejszego średniowiecznego komentarza do Talmudu, w strukturze stwarzania wyróżnił hierarchię, w której najniżej wyznacza przyrodę nieożywioną, wyżej rośliny i dalej zwierzęta. Na samym szczycie tej drabiny znajduje się człowiek, jako korona stworzenia (Jędrzejewski 2012: 349). Z kolei Robert Gordis zaznacza, że naczelną zasadę stosunku człowieka do świata przyrody wyznacza werset z Księgi Rodzaju $(2,15)$ : „Pan Bóg wziął zatem człowieka i umieścił go w ogrodzie Eden, aby uprawiał go i doglądał" (Gordis 1995: 328). Wobec takiej hierarchii w dyskursie judaistycznym, ale również chrześcijańskim pojawił się koncept dominacji człowieka nad naturą, wobec którego rozważania rozrosły się do wniosków, w których uważa się, że judeochrześcijańska wizja stworzenia i roli człowieka w świecie natury jest przyczyną kryzysu ekologicznego. Kryzys zgodnie z teorią Lynn White miał być spowodowany przyzwoleniem na eksploatację środowiska naturalnego, a człowiek w niej staje się panem ziemi i ma nad nią dominować (Kay 2001: 86-87). Ellen Berenstein podkreśla jednak, że taka argumentacja wynika z niezrozumienia tekstu, który powstał przed trzema tysiącami lat. W tym kontekście „dominacja” oznacza tyle co błogosławieństwo, boski akt miłości. Tak jak wszystkim zwierzętom, człowiekowi Bóg nakazał się 
rozmnażać, ale inaczej niż zwierzętom, każe stać. Nadaje mu zatem taką samą pozycję jak ma Bóg, aby mógł doglądać natury. Dominacja zatem bardziej niż darem, jest zadaniem, a jeżeli zadaniem to i odpowiedzialnością. Wobec takiego ujęcia koncept Tikkun Olam w kontekście ekologii staje się dużo bardziej czytelny.

Eric Rosenblum zaznacza, że Tikkun Olam we współczesnej teologii judaizmu podkreśla rolę jednostki w odkupieniu grzechów (Rosenblum 2001: 200). Odkupienie grzechów w tym znaczeniu, to indywidualna odpowiedzialność za siebie, ale również za zbiorowość. Zatem akcentuje się, że każda osoba zobligowana jest do działania na rzecz naprawy świata. Rosenblum definiuje Tikkun Olam jako „proces bezpośredniej interwencji człowieka w celu przywrócenia naturalnej funkcji ekosystemów, których działanie zostało zakłócone przez człowieka" (Rosenblum 2001: 200).

\subsection{Przyroda dla człowieka}

O ile środowisko naturalne stanowi zasadniczy trzon egzystencji człowieka, a wszelkie działania proekologiczne są jedną $\mathrm{z}$ form współczesnego rozumienia wypełniania Tikkun Olam, to środowiska żydowskie coraz częściej zauważają jednak niebezpieczeństwo, jakie niesie za sobą przewartościowanie natury, pryncypialne jej traktowanie. Taką tendencją zaniepokojony był żydowski filozof Abraham Joshua Heschel pisząc o romantyzmie, jako epoce wnoszącej zmiany światopoglądowe: „Natura zyskała najwyższe uznanie i stała się przedmiotem najwyższej adoracji, jedynym źródłem pocieszenia i zbawienia, i ostatecznym sędzią wartości. Jej umiłowanie, trwanie $\mathrm{z}$ nią $\mathrm{w}$ jedności, otwarcie się na jej uzdrawiające współodczuwanie było najwyższą formą religijnego doświadczenia"(Heschel 2008:114). Wiek XIX stał się początkiem okresu reorientacji wartości. Natura - stworzenie - zajęła pozycję wyższą niż sam Stwórca, czego symbolem stało się mówienie o Matce Naturze, a także swoista trywializacja wartości człowieka, jako stworzenia na obraz i podobieństwo
Boga. Dlatego judaizm stoi na stanowisku, że wszelkie zacieranie różnic między ludźmi a zwierzętami, czy środowiskiem flory, które współcześnie jest coraz bardziej popularne, rodzi niebezpieczeństwo: „Gdy życie zwierzęcia znaczy aż tyle, co życie człowieka, wtedy wartość człowieka ma tylko wartość zwierzęcia"(Heschel 2008: 347). Stąd judaizm podkreśla, że natura posiada wysoką wartość, ale nie jest wartością najwyższą. Najbardziej widocznym tego elementem jest fakt, że na dziesięć przykazań, tylko jedno trzecie przykazanie - dotyczące uświęcania Szabatu, pośrednio wskazuje na potrzebę ochrony środowiska. Dlatego należy pamiętać, że judaizm zawiera tylko „zielone” elementy, ale nie jest „zieloną” religią. Człowiek stanowi zatem część natury, ale tylko część, bowiem posiada przywilej panowania nad nią, a nie jej ulegania; przyroda ma być chroniona, ale nie kosztem człowieka.

\section{Zakończenie}

Żydowski koncept Tikkun Olam - naprawy świata, choć mający korzenie w księgach biblijnych, współcześnie przybiera coraz szerszy zakres. Postępująca degradacja środowiska, która obecnie zagraża już nie tylko samej przyrodzie, ale staje się zagrożeniem również dla człowieka skłania do podejmowania działań na rzecz odbudowy naturalnych ekosystemów i ochrony tych, które nie zostały jeszcze naruszone przez działalność ludzką. Zagrożenia ekologiczne i konieczność zapobiegania ich występowaniu stają się obecnie działaniem priorytetowym, a ekologia jest już nauką interdyscyplinarną. Wobec tak szerokiego problemu swoje stanowisko zajmują również wyznawcy judaizmu, podkreślając, że ochrona środowiska przyrodniczego jest nakazem wypływającym już z ksiąg biblijnych, a więc ma źródło stanowione nie prawem ludzkim, a boskim, co dla wyznawców judaizmu, jako orędowników tradycji wiąże się z niepodważalnością tego prawa.

Tikkun Olam czyli wezwanie do naprawy świata jest na tyle ważne, że wypowiada je każdy pobożny żyd podczas codziennej 
modlitwy. Zatem nie stanowi już tylko okazjonalnego manifestu, ale jest komponentem życia, w którym każdy powinien podejmować czyny, które będą skutkowały konkretnym efektem. Tak silny przekaz tego hebrajskiego wezwania powoduje, że przyjęto w jego znaczeniu również kontekst właśnie ekologiczny. Tikkun Olam nie wskazuje na potrzebę dokonywania spektakularnych przedsięwzięć w tej dziedzinie, a wprost przeciwnie, nakazuje powrót do przykazań zawartych w księgach biblijnych. Ta naprawa odbywa się bowiem w zwykłych, codziennych czynnościach, które winniśmy zmieniać jeżeli tylko okaże się, że mają destruktywny wpływ na drugiego człowieka czy przyrodę. Judaizm próbuje zatem wskazywać na harmonię, a tym samym znosi wszelkie dystynkcje pomiędzy Bogiem, człowiekiem, a przyrodą.

\section{Bibliografia}

Banaszak J., Wiśniewski H., 1999, Podstawy ekologii, Wydawnictwo Uczelniane WSP w Bydgoszczy, Bydgoszcz.

Bernstein E., 1998, Introduction, in: Bernstein E. (eds) Ecology and the Jewish Spirit: Where Nature and the Sacret Meet, Woodstock, 11-14.

Dziekoński S., 2011, Znaczenie katechezy w edukacji ekologicznej, Pedagogia Christiana, 2, 179-193.

Gordis R., 1995, Ecology and the Judaic Tradition, in: Dorff E. N., Newmann L. E. (eds), Contemporary Jewish Ethics and Morality, Oxford University Press, New York, 328-332.

Gottliebb R. S., 2006, Introduction: Religion and Ecology - What Is the Connection and Why Does It Matter, in: Gottlieb R. S. (eds) Religion and Ecology, Oxford University Press, Oxford/New York, 3 - 21.

Heschel A.J., 2008, Bóg szukajacy człowieka, Espirit, Kraków.

Kay J., 2001, Concept of Nature in the Hebrew Bible, in: Yaffe M.D. (eds), Judaism and Environmental Ethics: A Reader., Lexington Books, 86 - 104.

Rosenblum E., 2001, Is Gaia Jewish? Finding a Framework for Radical ecology in Traditional Judaism, in: Yaffe M.D. (eds), Judaism and Environmental Ethics: A Reader., Lexington Books, 183-205.

Szlaga J. B., 1998, Powtórka z Biblii, „Bernardinum”, Pelplin.
Szczerbiński W., 2001, Istota etyki żydowskiej, Colloquiatheologica Adalbertina, IV/2, 41-64.

Tirosh-Samuelson H., 2006, Judaism, in: Gottlieb R. S. (eds) The Oxford Handbook of Religion and Ecology, Oxford University Press, Oxford/New York, $25-64$.

Tora Pardes Lauder. Ksiega Pierwsza: Beteszit, 2001, wyd. Pardes Lauder, Kraków.

Tyburski W., 2006, Powstanie i rozwój filozofii ekologicznej, Problemy ekorozwoju, vol. 1, No1, 7 - 15.

Waskow A., 200o, Earth and Earthling. Adam and Adamah, in: Waskow A. (eds), Torah of the Earth Vol.1: Exploring 4.ooo Years of Ecology in Jewish Thought, Jewish Light Publishing.

(Web-01) B. Sheerwin, Tikkun Olam: a case to semantic displacement, http://jcpa.org/article/tikkun-olam-case-semantic-displacement, dostęp: 25.05.2016.

(Web-02) N. Zion, Tikkun Olam: A New Terminology for Social and Economic Reform and its Biblical, Rabbinic and Mystical Roots, dostęp: 25.05.2016.

(Web-o3) L. Troster, Tikkun Olam and Environmental Restoration: A Jewish Eco-Theology of Redemption, http://bjpa.org/Publications/downloadFile.cfm?FileID=4659, dostęp: 3.05.2016.

(Web-) J. Jacobs, The History of „Tikkun Olam”, http:// www.zeek.net/7o6tohu/, dostęp: 6.12.2016.

(Web-04) L. Cooper, The Assimilation of Tikkun Olam, http://www.bjpa.org/Publications/details. cfm?PublicationID=22235, dostęp: 3.05.2015.

(Web-05 po zm.) Tikkun olam, http://www.reformjudaism.org.uk/tikkun-olam/, dostęp: 2.12.2016.

(Web-06) Y. A Korff, The Fallacy, Delusion and Myth of Tikkun Olam, http://www.algemeiner. com/2013/o6/o7/the-fallacydelusion-and-myth -of-tikkun-olam/, dostęp: 27.04.2015

(Web-07) D. Vogel, How green is Judaism. Exploring Jewish Environmental Ethics, http://eds.b.ebscohost.com/eds/pdfviewer/pdfviewer?sid= $727 \mathrm{~d} 82 \mathrm{e} 4$-fd8b-45a3-8fb2-47ddoe2976dd \%40sessionmgr112\&vid $=7 \&$ hid $=103$, dostęp: 5.05.2015.

(Web-o8) D. Fink, Judaism and Ecology: A Theology of Creation, http://fore.yale.edu/religion/judaism/, dostęp: 7.03.2017. 


\section{Tikkun Olam. The Jewish vision of „Repairing the world" and it's ecological explications}

\section{Summary}

In jewish theology and philosophy the problem of nature seems to be hidden, the nature seems to be in the shadow of man. However, the fact of environmental degradation undoubtedly has a huge impact on man. That is why ecology and the environment are becoming a problem that increasingly appears in Jewish thought. Jewish environmental protection is often connected with concept of Tikkun Olam, which mean reparing the world or restoration of world. The Biblical roots of Tikkun Olam encourage us to study the meaning of nature and man in it. So we are instructed what is the place of man in the natural environment and what is our task in terms of nature. The concept of Tikkun Olam obliges us to permanent activities for nature that we should improve and take care of it. The biblical message and its transcendent source may be much stronger than human law. Therefore, the Judaic vision of ecology can also be an interesting proposition in the approach to the care for the environment.

\section{Key words}

judaism, ecology 